\title{
Promosi Kesehatan Nola Pender Berpengaruh terhadap Pengetahuan dan Kepatuhan ODHA Minum ARV
}

\author{
Tuti Asrianti Utami \\ Sekolah Tinggi Ilmu Kesehatan Sint Carolus \\ Salemba Raya 41 Jakarta Pusat 10440 \\ Email: tutichaidir@yahoo.com
}

\begin{abstract}
Abstrak
Tingkat keberhasilan terapi ARV sangat tergantung dari kepatuhan pasien HIV dalam menjalankan terapi ARV. Tujuan penelitian ini adalah menganalisa pengaruh promosi kesehatan Nola Pender terhadap peningkatan pengetahuan dan kepatuhan ODHA minum ARV di Pelayanan Kesehatan Sint Carolus (PKSC) dan Rumah Sakit Umum Pusat Persahabatan (RSUPP). Desain penelitian yang digunakan adalah Pre-Post test Quasi Eksperimental Non Equivalent Control Group dengan total sampel 90 responden diperoleh melalui purposive sampling sesuai kriteria inklusi sebesar 45 responden ODHA di PKSC (kelompok intervensi) dan sisanya sebagai kelompok kontrol di RSUPP pada bulan Mei-Juni 2016. Hasil penelitian menunjukkan karakteristik responden terbanyak usia dewasa akhir (36-55 tahun), laki-laki, berpendidikan lanjut, bekerja, pernah mendapat layanan konseling, mendapat dukungan keluarga dan dukungan teman sebaya, jarak layanan kesehatan mudah ditempuh dan mempunyai jaminan layanan kesehatan. Promosi kesehatan Nola Pender meningkatkan pengetahuan tentang ARV dari rata-rata nilai 5,31 menjadi 7,04 dan meningkatkan kepatuhan minum ARV dari kepatuhan sedang menjadi kepatuhan baik sebanyak $51,1 \%$. Pengaruh promosi kesehatan Nola Pender dengan menggunakan booklet meningkatkan pengetahuan responden $(p=0,000)$ dari 13,3\% menjadi 91,1\%. Peningkatan pengetahuan tentang ARV berpengaruh terhadap kepatuhan minum $\operatorname{ARV}(p=0,000)$, dikontrol oleh variabel dukungan teman sebaya, dari 30,2\% menjadi 87,2\%. Penelitian ini merekomendasikan perlunya dilanjutkan promosi kesehatan Nola Pender pada ODHA dengan ARV yang terprogram dan terstruktur secara berkelanjutan
\end{abstract}

Kata Kunci: promosi kesehatan Nola Pender, pengetahuan, kepatuhan, ODHA, ARV

\section{Nola Pender's Health Promotion Influence The Knowledge and Adherence PLWHA ARV Drinking}

\begin{abstract}
The success rate of ARV therapy depends on the adherence of HIV-AIDS patients in ARV treatment. The purpose of this study was to analyze the effect of NolaPender health promotion to improve the knowledge and adherence of PLWHA (People living with HIV-AIDS) with ARV in SintCarolus Health Service (SCHS) and Persahabatan General Hospital (PGH). This study used a Pre-Post test Quasi Eksperimantal Non Equivalent Control Group and a total sample of 90 respondents were recruited through the use of consecutive sampling with inclusion criteria where 45 respondents served as intervention group in SCHS and the remaining as control group in PGH from May-June 2016. The result showed most respondents were in the late adulthood stage (36-55 years old), male, having advanced education, working, exposed to counseling service, having family support as well as peer group support, easy in reaching health service and with health insurance. NolaPender health promotion increased the knowledge of ARV (mean score pre intervention was 5.31 to post intervention 7.04), and improving the adherence of taking ARV from moderate to good adherence as many as $51.1 \%$. There was an effect of Nola Pender health promotion using booklet to respondents' knowledge ( $p$-value=0.000) from $13.3 \%$ to $91.1 \%$ and also effect of knowledge improvement of $A R V$ to the adherence of taking $A R V$, with the support from peer group from
\end{abstract}


$30.2 \%$ to $87.2 \%$. The study recommends to continue this program of Nola Pender health promotion for PLWHA taking ARV in a structured and well planned system.

Keywords: Nola Pender health promotion, knowledge, adherence, people living with HIV-AIDS, ARV.

Info Artikel:

Artikel dikirim pada 20 Januari 2017

Artikel diterima pada 27 Maret 2017

DOI : http://dx.doi.org/10.21927/jnki.2017.5(1).58-67

\section{PENDAHULUAN}

HIV (Human Immunodeficiency Virus) adalah virus yang menyerang sistem kekebalan tubuh manusia dan mengakibatkan AIDS (Acquired Immunodeficiency Sindrom) merupakan sekumpulan gejala abnormalitas imunologis dan gejala klinis $(1,2)$.

Terapi Antiretroviral (ARV) adalah terapi khusus bagi orang dengan HIV AIDS (ODHA), terapi ini tidak dapat menyembuhkan, hanya memaksimalkan supresi replikasi HIV dan viral load menjadi lebih rendah atau tidak terdeteksi dan peningkatan CD4 sehingga terhindar dari infeksi oportunistik (3). Tujuan terapi ARV untuk memelihara imunitas tubuh, meningkatkan kualitas hidup, mengurangi morbiditas serta mortalitas terkait HIV (4).

Langkah penting menanggulangi HIVIAIDS dengan meningkatkan pengetahuan dan kepatuhan ODHA minum ARV (3). Pengetahuan adalah hasil tahu seseorang terhadap objek melalui indera yang dimilikinya, yang mempunyai tingkat yang berbedabeda (5). Pengetahuan ODHA tentang terapiARV dapat mempengaruhi kepatuhan dalam mengikuti aturanaturan yang disepakati. Keterbatasan pengetahuan adalah hambatan terhadap kepatuhan terapi ARV, sebaiknya ODHA dapat memperoleh manfaat dari bahan promosi kesehatan Nola Pender secara rinci tentang terapi ARV (6). Peningkatan pengetahuan diukur dengan cara memberikan pertanyaan secara tertulis menggunakan kuisioner (7).

Pengetahuan tentang manfaat terapi ARV penting diketahui oleh ODHA untuk meningkatkan perilaku memelihara kesehatannya. Penelitian tentang Knowledge and attitudes regarding HIV/ AIDS and antiretroviral therapy among patients at a Nigerian treatment clinic, dari 318 ODHA sebagai responden menyatakan bahwa pengetahuan yang baik mengenai HIVIAIDS dan mempunyai sikap positif tentang penyakit ini akan menjadi lebih patuh terhadap ARV $(p<0,01)$ dengan kepatuhan $>95 \%$
(8). Ketidakpatuhan atau adherence yang buruk merupakan alasan utama terjadinya kegagalan pasien dalam menjalani pengobatan ARV, sehingga kepatuhan harus dipantau dan dievaluasi secara teratur serta diberikan support setiap kali kunjungan (3). Tingkat kepatuhan pengobatan ARV di Indonesia sangat rendah, yaitu $40-70 \%$ yang masih di bawah target nasional dengan tingkat kepatuhan 95\% (9). Kepatuhan dapat menurun jika pasien merasakan efek samping obat, setelah menjalani ARV pada 6-12 bulan dan 12-24 bulan dibandingkan dengan yang telah lama melakukan terapi ARV (9). Penelitian Kammerer et al, menjelaskan bahwa semakin lama terapi dan sakit yang diderita, resiko terjadinya penurunan tingkat kepatuhan terapi semakin tinggi (10).

Untuk meningkatkan kepatuhan ODHA minum ARV perlu adanya promosi kesehatan. Promosi kesehatan mencakup aspek perilaku yaitu upaya untuk memotivasi, mendorong dan membangkitkan kesadaran akan potensi yang dimiliki masyarakat agar mereka mampu memelihara dan meningkatkan kesehatan dirinya (11). Promosi kesehatan yang telah dilakukan di PK Sint Carolus dan RSUP Persahabatan diantaranya dengan memberikan konseling mengenai tata laksana minum ARV yang diberikan sebelum ODHA memulai minum ARV. ODHA yang minum ARV harus patuh ARV untuk seumur hidupnya. Untuk itu peneliti merasa penting memberikan promosi kesehatan Nola Pender diantara waktu minum ARV setidaknya setiap enam sampai dua belas (6-12) bulan, untuk mengingatkan ODHA supaya tetap mempunyai motivasi dan komitmen untuk patuh ARV.

Berdasarkan hasil rekam medik dan pemilihan pasien untuk menjadi responden di PK Sint Carolus dan RSUP Persahabatan rata-rata kepatuhan ODHA minum ARV sebelum intervensi adalah kepatuhan sedang (kepatuhan 80-95\%). Penelitian ini melakukan pendekatan intervensi menggunakan teori Health 
Promotion Model (HPM) atau Model Promosi Kesehatan merupakan konsep model berdasarkan upaya pada pemberdayaan kemampuan individu atau keluarga untuk meningkatkan derajat kesehatan dan kualitas hidupnya (11). HPM membantu perawat dalam menolong pasien mengidentifikasi faktor risiko terhadap kesehatan dan perilaku sehat yang sudah pernah dilakukan dalam rangka membentuk perilaku baru yang dapat mencapai status kesehatan yang optimal (12). Peran perawat dalam promosi kesehatan Nola Pender adalah mencegah ODHA ke kondisi yang lebih buruk, dengan mengajak individu dan peran serta lingkungan agar berperilaku positip terhadap pemeliharaan dan peningkatan kesehatan, meningkatkan motivasi dan komitmen ODHA agar lebih patuh ARV (11).

ODHAharus minumARV, demi mempertahankan hidupnya, mencegah infeksi yang lebih luas, selama sepanjang usianya. Kepatuhan minum ARV yang rendah dapat mempengaruhi ketidakberhasilan dalam meningkatkan kesehatannya, sehingga diperlukan promosi kesehatan. Promosi kesehatan Nola Pender bermanfaat untuk memberikan motivasi, membangun kesadaran akan potensi yang dimiliki individu dan masyarakat agar mampu memelihara dan meningkatkan kesehatan dirinya dengan lebih patuh minum ARV. Tujuan penelitian untuk menganalisa pengaruh promosi kesehatan Nola Pender terhadap pengetahuan dan kepatuhan ODHA minum ARV di Pelayanan Kesehatan (PK) Sint Carolus dan Rumah Sakit Umum Pusat (RSUP) Persahabatan Jakarta.

\section{BAHAN DAN METODE}

Penelitian dilakukan di Poli Carlo PK Sint Carolus dan Poli rawat jalan Infeksi Penyakit Dalam RSUP Persahabatan Jakarta. Waktu penelitian dilakukan Bulan Mei sampai Juni 2016. Populasi merupakan kumpulan individu atau subyek yang memenuhi kriteria yang telah ditetapkan (13). Populasi penelitian ini terdiri dari ODHA di Poli Carlo PK Sint Carolus, berdasar data rata-rata ODHA rawat jalan yang minum ARV dan sesuai kriteria inklusi berjumlah 90 pasien selama bulan Februari 2016, ODHA di Poli rawat jalan Infeksi Penyakit Dalam, RSUP Persahabatan berdasar data rata-rata rekam medik pasien rawat jalan ODHA yang minum ARV dan berdasar inklusi berjumlah 70 pasien setiap minggu. Penelitian ini merupakan penelitian non eksperimental dengan metode sampling nonprobability sampling, sehingga tidak semua ODHA yang berada dalam populasi memiliki kemungkinan yang sama untuk terpilih menjadi sampel. Bentuk nonprobability sampling yang digunakan adalah purposive sampling. Pasien yang dapat berpartisipasi adalah yang memenuhi kriteria inklusi yaitu bersedia menjadi responden, bersedia menandatangani surat pernyataan, sedang minum ARV selama antara 1-12 bulan, usia responden antara 18-50 tahun, ibu hamil HIV positif yang minum ARV, pasien rawat jalan. Kriteria eksklusi penelitian ini ODHA yang drop out pengobatan, ODHA yang mengalami infeksi opurtunistik berat. Perhitungan jumlah sampel ini menggunakan desain pre dan post kontrol group. Peneliti membagi menjadi dua kelompok yaitu kelompok intervensi yang dilakukan intervensi dan kelompok kontrol yang tidak dilakukan intervensi $(13,14)$. Jumlah sampel ditentukan dengan menggunakan rumus uji hipotesis beda proporsi (15). Pertimbangan sampel error dan pembulatan maka menjadi 45 responden terdiri dari 45 responden dari kelompok intervensi, pasien Poli Carlo PK Sint Carolus dan 45 responden kelompok kontrol, pasien rawat jalan RSUP Persahabatan, sehingga total 90 responden. Media konseling yang digunakan berupa booklet hurufnya berbagai macam, isinya padat, cukup menarik, meteri terbatas sesuai dengan informasi yang ingin disampaikan. Materi promosi kesehatan Nola Pender terdiri dari pengertian ARV, bagaimana cara menggunakan ARV, manfaat ARV, persiapan pemberian ARV, syarat menggunakan $A R V$, aturan dan jenis ARV di Indonesia, pemantauan ODHA, tingkat kepatuhan minum ARV dan motivasi untuk Patuh ARV. Alat ukur berupa 8 pertanyaan terkait ARV.

Promosi kesehatan Nola Pender diberikan kepada 45 responden kelompok intervensi di Poli Carlo PKSC pada pertemuan pertama. Dilakukan secara individu dengan tanya jawab, dan kelompok kontrol tidak diberikan intervensi, alokasi waktu untuk promosi kesehatan Nola Pender selama 30-40 menit dan diberikan Booklet Patuh ARV, responden dianjurkan untuk melakukan kunjungan ulang setelah 2 dan 4 minggu. Pelaksanaan post test sebagai berikut saat responden melakukan kunjungan ulang setelah 2 dan 4 minggu untuk melakukan pengambilan obat, peneliti mencatat sisa obat. Pengukuran post test dilakukan setelah 4 minggu pada kelompok intervensi dan kelompok kontrol, dengan memberikan kuisioner yang sama pada saat pre test. Kelompok kontrol diberikan 
promosi kesehatan Nola Pender dalam kelompok kecil 2-4 orang dan diberikan booklet Patuh ARV. Memastikan seluruh data disi dilanjutkan pada tahap pengolahan data.

Instrumen penelitian terdiri dari kuesioner $A$ yang merupakan instrumen untuk mengetahui data demografi. Kuesioner ini terdiri dari nomor kode responden, usia, jenis kelamin, pendidikan, pekerjaan, layanan konseling sebelumnya, dukungan keluarga, dukungan teman sebaya, jarak dan jaminan layanan kesehatan. Kuesioner B adalah instrumen untuk mengukur hasil pre test dan post test. Kuesioner ini merupakan 8 pertanyaan mengenai pengetahuan dan kepatuhan terapi ARV. Setiap jawaban yang benar mendapat nilai 1 dan salah mendapat nilai 0 , dengan nilai skor tertinggi 8 dan skor terendah adalah 0 . Kuesioner B telah dilakukan uji validitas dan reliabilitas pada bulan April 2016 di Yayasan Pelita IImu Tebet, Jakarta pada 31 responden ODHA yang menggunakan ARV selama 1-12 bulan.

Analisis univariat yang disajikan meliputi frekuensi dan persentasi. Analisis bivariat dengan uji Wilcoxon dilakukan untuk mengetahui perbedaan tingkat pengetahuan dan kepatuhan sebelum dan sesudah dilakukan intervensi (before-after) pada kelompok intervensi. Uji beda berpasangan yang digunakan dalam penelitian ini adalah uji Wilcoxon (16). Uji beda independen non parametrik digunakan untuk menganalisis perbedaan tingkat pengetahuan dan kepatuhan antara kelompok yang diberikan intervensi promosi kesehatan Nola Pender dengan kelompok kontrol. Uji beda independen dilakukan dengan uji beda independen non parametrik statistik sebab skala tingkat pengetahuan dan kepatuhan mengunakan skala nominal (16). Uji chi-square dilakukan untuk mengetahui pengaruh antara variabel perancu dan peningkatan pengetahuan, selain itu pengaruh antara variabel perancu dan kepatuhan. Nilai confidence interval $95 \%$ dengan tingkat kemaknaan $5 \%(a=0,05)$. Jika nilai $p<0,05$ maka hipotesis diterima yang artinya kedua variabel ada pengaruh. Analisis multivariat dengan menggunakan uji Regresi Logistik Binary yaitu untuk mengkaji tingkat probabilitas perlakuan promosi kesehatan Nola Pender pada pasien ODHA. Penelitian ini menganalisis variabel independen pada peningkatan pengetahuan dan variabel perancu, sedangkan variabel independen lainnya peningkatan kepatuhan ODHA dan variabel perancu yang berpengaruh dengan $p$-value $<0,25$.

\section{HASIL DAN BAHASAN}

\section{Hasil Analisis Univariat}

Hasil analisa ini menyajikan analisa data statistik secara deskriptif dari beberapa variabel, yang disajikan meliputi frekuensi dan persentasi.

Tabel 1. Distribusi Responden Berdasarkan Variabel Perancu pada Pengetahuan di PK Sint Carolus dan RSUP Persahabatan Jakarta, Mei-Juni 2016

\begin{tabular}{lcc}
\hline \multicolumn{1}{c}{ Keterangan } & f & $\%$ \\
\hline Usia & & \\
$\quad$ Dewasa Muda (18-35 tahun) & 77 & 14,4 \\
$\quad$ Dewasa Akhir (36 tahun-50 tahun) & & \\
Jenis Kelamin & 68 & 75,6 \\
$\quad$ Laki-laki & 22 & 24,4 \\
$\quad$ Perempuan & & \\
Pendidikan & 18 & 20 \\
$\quad$ Pendidikan Dasar (Tidak Sekolah-SMP) & 72 & 80 \\
$\quad$ Pendidikan Lanjut (SMA-Perguruan Tinggi) & & \\
Pekerjaan & 23 & 25,6 \\
$\quad$ Tidak bekerja & 65 & 72,2 \\
$\quad$ Bekerja & & \\
Layanan Konseling Sebelumnya & 25 & 27,8 \\
$\quad$ Tidak Selalu Mendapat Konseling & 65 & 72,2 \\
$\quad$ Selalu Mendapat Konseling & & \\
\hline
\end{tabular}

Sumber: Data Primer Tahun 2016

Berdasarkan Tabel 1 penelitian ini distribusi rata-rata usia responden antara 36-50 tahun (dewasa akhir) sebanyak 85,6\%. Penelitian Martoni menyatakan bahwa HIV AIDS dapat terjadi pada semua usia, prevalensi tertinggi dari 55 responden $54,5 \%$ berusia lebih dari 30 tahun dengan kepatuhan $83,3 \%$ (17). Pengalaman peneliti dan keterkaitan dengan penelitian lain bahwa laki-laki lebih banyak dibandingkan perempuan karena laki-laki sebelumnya mempunyai pengalaman individu yang berpengaruh pada keadaannya sekarang (11). Sebelumnya mengalami perubahan gaya hidup sebagai gay yang melakukan hubungan LSL, laki-laki lebih mudah melakukan perilaku beresiko, ketertarikan dengan sesama jenis dan sebagian responden mengatakan harus bekerja jauh dari istrinya sampai melakukan hubungan seks diluar nikah (17).

Pendidikan responden dalam penelitian ini terbanyak pada pendidikan lanjut $80 \%$. Tingkat pendidikan seseorang diduga dapat mempengaruhi pengetahuan, sikap dan perilaku, namun tingkat pendidikan tidak selalu berbanding lurus dengan perilaku sehat (3). Didukung oleh penelitian Lubis R, responden HIV $37,84 \%$ berpendidikan lanjut, 
$24,32 \%$ tidak sekolah, $16,22 \%$ SD dan $21,62 \%$ SMP (18). Pengalaman peneliti, responden dengan pendidikan lanjut akan mempunyai pekerjaan dan penghasilan yang lebih baik dibandingkan dengan responden dengan tingkat pendidikan rendah, sehingga dengan penghasilan tersebut responden melakukan perubahan gaya hidup dan pergaulan bebas.

Hasil penelitian ini responden yang bekerja $72,2 \%$. HIVIAIDS lebih berdampak pada orang bekerja pada sektor produktif. Gay merupakan populasi kunci beresiko tinggi terkena HIVIAIDS dengan terbatasnya lahan kerja maka gay terpaksa melakukan pekerjaan rentan terhadap penyakit yang menyerang imun tubuh, akhirnya gay akan terus lahir dan meningkat jumlahnya (19). Responden yang bekerja mempunyai penghasilan untuk membiayai life style nya dengan perilaku homoseksual ataupun heteroseksual.

Responden pada penelitian ini yang merasakan pelayanan konseling sebelumnya $72,2 \%$. Penelitian Chaiyachati, tahun 2014 dimana responden diberikan bimbingan konseling tentang HIVIAIDS dan kepatuhan ARV maka responden dengan pengetahuan yang baik dan sikap positif terhadap HIVIAIDS cenderung lebih patuh $p$-value $<0,01$ (20). Berdasar pengalaman peneliti, bahwa promosi kesehatan melalui konseling kepatuhan yang telah dilakukan akan membantu pasien mencari jalan keluar dari kesulitan yang timbul sebelum memulai minum ARV, yang mempengaruhi kepatuhan minum ARV.

Berdasar Tabel 2 distribusi responden yang mendapat dukungan keluarga sebanyak $59,2 \%$. Keluarga berperan memberikan perlindungan,

Tabel 2. Distribusi Responden Berdasarkan Variabel Perancu pada Kepatuhan di Poli Carlo PKSC dan Poli Rajal IPD RSUP Persahabatan Jakarta, Mei-Juni 2016

\begin{tabular}{lcc}
\hline \multicolumn{1}{c}{ Keterangan } & f & \% \\
\hline Dukungan Keluarga & & \\
$\quad$ Tidak Ada Dukungan & 41 & 45,6 \\
$\quad$ Ada Dukungan & 49 & 54,4 \\
Dukungan Teman Sebaya & & \\
$\quad$ Tidak Ada Dukungan & 33 & 36,7 \\
$\quad$ Ada Dukungan & 57 & 63,3 \\
Jarak Layanan Kesehatan & & \\
$\quad$ Mudah & 73 & 81,1 \\
$\quad$ Sulit & 17 & 18,9 \\
Jaminan Layanan Kesehatan & & \\
$\quad$ Tidak Ada Jaminan & 29 & 32,2 \\
$\quad$ Ada Jaminan & 61 & 67,8 \\
\hline
\end{tabular}

Sumber: Data Primer Tahun 2016 psikososial dan dukungan serta penghargaan yang dapat meningkatkan kesejahteraan dan kualitas hidup pasien (21). ODHA yang mendapatkan dukungan dari keluarganya merasa mempunyai semangat dalam dirinya bahwa ia diperhatikan dan disayangi oleh orang-orang disekitarnya (22). Berdasar pengalaman peneliti dan sesuai dengan perasaan individu yang diungkapkan oleh Pender, tahun 2011 bahwa responden yang melakukan kunjungan didampingi oleh keluarganya tampak responden merasa lebih nyaman, lebih happy dan mudah diajak komunikasi karena responden merasa mendapatkan dukungan dari keluarga atas perilaku sehat dan pengobatan yang dijalaninya (11).

Penelitian ini menjelaskan responden yang mendapat dukungan teman sebaya sebanyak $66,7 \%$. Secara teori dukungan teman sebaya atau komunitas dapat menumbuhkan perasaan nyaman, percaya, dihormati, dihargai, dicintai, dan bahwa orang lain bersedia memberikan perhatian dan keamanan (23). Berdasar pengamatan peneliti, selama melakukan pertemuan dengan responden sebagian responden merasa khawatir akan pengungkapan status ODHA di komunitas akan membawa dampak negative yang serius bagi laki-laki maupun perempuan. Bahkan ODHA merasa sangat khawatir akan stigmatisasi ekstrim yang terjadi ketika seorang petugas kesehatan mengungkapkan status mereka ke masyarakat luas.

Responden yang merasakan mudahnya jarak layanan kesehatan dalam penelitian ini sebanyak $60,3 \%$. Jarak layanan kesehatan mudah jika jarak dari tempat tinggal responden $<20$ kilometer dan jarak tempuh yang sulit jika jarak dari tempat tinggal responden $>20$ kilometer (6). ODHA yang tempat tinggalnya jauh dari layanan mempunyai resiko untuk mangkir karena tidak memiliki biaya transportasi ke layanan sehingga pada akhirnya kehabisan obat. Berdasar pengamatan peneliti, ODHA yang melakukan kunjungan mempunyai harapan yang berbeda dari usaha yang dilaluinya untuk mencapai layanan kesehatan. Sebagian ODHA, merasakan yang penting mendapat petugas kesehatan yang cepat tanggap dan menjaga kerahasiaan status responden menjadi lebih penting.

Responden yang memiliki jaminan layanan kesehatan sebanyak $57,4 \%$. Jaminan layanan kesehatan dapat lebih meringankan biaya pengobatan dan perawatan, permasalahan finansial ini secara tidak langsung bisa mengakibatkan rendahnya kepatuhan 
ODHA dalam minum ARV (21). Penyediaan ARV gratis.harus disiapkan melalui puskesmas secara berkesinambungan dan terorganisasi dengan baik sampai ke seluruh wilayah. Bahkan perlu adanya dukungan paket perawatan lainnya seperti profilaksis kotrimoksazol, konseling, manajemen infeksi oportunistik dan penyakit penyerta, dukungan nutrisi (24).

Berdasarkan Tabel 3 menjelaskan bahwa ratarata pengetahuan ODHA tentang ARV pada kelompok kontrol yang tidak diberikan promosi kesehatan Nola Pender, pre test sebesar $59,17 \%$ sedangkan post test $58,33 \%$. Kelompok intervensi mengalami peningkatan setelah diberi intervensi promosi kesehatan Nola Pender, pada pre test sebesar $66,8 \%$ dan post test sebesar $88,06 \%$, dengan rata-rata nilai dari 5,31 meningkat pada saat post test menjadi 7,04. Jawaban responden yang benar dan mengalami peningkatan terbanyak setelah diberi intervensi promosi kesehatan Nola Pender adalah pertanyaan tentang manfaat ARV sebesar $28,9 \%$ dari $66,7 \%$ ke $96,6 \%$.

Berdasarkan Tabel 4 menjelaskan bahwa ratarata kepatuhan ODHA minum ARV pada minggu I yang terbanyak adalah kepatuhan sedang pada kelompok kontrol $80 \%$, dan kelompok intervensi $57,8 \%$. Pada minggu 4 kepatuhan terbanyak pada kelompok kontrol adalah kepatuhan sedang $84,4 \%$, sedangkan sesudah diberi intervensi promosi kesehatan pada kelompok intervensiterbanyak adalah kepatuhan baik $95,6 \%$.

\section{Hasil Analisis Uji Beda}

Uji Wilcoxon termasuk dalam pengujian nonparametrik, dilakukan untuk membandingkan antara dua kelompok data yang saling berhubungan uji ini mempunyai kekuatan test yang lebih dibandingkan dengan sign test (16).

Berdasarkan Tabel 5 menjelaskan bahwa responden yang meningkat pengetahuannya pada kelompok kontrol 13,3\% lebih rendah dibandingkan dengan kelompok intervensi $91,1 \%$. Ada pengaruh yang bermakna antara promosi kesehatan Nola Pender terhadap peningkatan pengetahuan di Poli Carlo PK Sint Carolus ( $p$-value 0,000).

Berdasarkan Tabel 6 menjelaskan bahwa responden kelompok kontrol meningkatnya kepatuhan $30,2 \%$ lebih rendah dibandingkan dengan responden kelompok intervensi sebesar $87,2 \%$. Ada pengaruh

Tabel 3. Distribusi Frekuensi Pengetahuan Responden tentang ARV di Poli Carlo PKSC dan Poli Rajal IPD RSUP Persahabatan Jakarta, Mei-Juni 2016

\begin{tabular}{|c|c|c|c|c|c|c|c|c|}
\hline \multirow{3}{*}{ Pertanyaan } & \multicolumn{4}{|c|}{ Kelompok Kontrol } & \multicolumn{4}{|c|}{ Kelompok Intervensi } \\
\hline & \multicolumn{2}{|c|}{$\begin{array}{c}\text { Pre Test } \\
\text { Jawaban Benar }\end{array}$} & \multicolumn{2}{|c|}{$\begin{array}{c}\text { Post Test } \\
\text { Jawaban Benar }\end{array}$} & \multicolumn{2}{|c|}{$\begin{array}{c}\text { Pre Test } \\
\text { Jawaban Benar }\end{array}$} & \multicolumn{2}{|c|}{$\begin{array}{c}\text { Post Test } \\
\text { Jawaban Benar }\end{array}$} \\
\hline & $f$ & $\%$ & f & $\%$ & f & $\%$ & f & $\%$ \\
\hline Pengertian ARV & 21 & 46,7 & 21 & 46,7 & 25 & 55,6 & 37 & 82,2 \\
\hline Manfaat ARV & 36 & 80 & 36 & 80 & 30 & 66,7 & 43 & 95,6 \\
\hline Mekanisme ARV & 18 & 40 & 18 & 40 & 31 & 68,9 & 40 & 88,9 \\
\hline Siapakah yang Mengkonsumsi ARV & 23 & 51,1 & 23 & 51,1 & 36 & 80 & 42 & 93,3 \\
\hline Anda Perlu Minum ARV & 30 & 66,7 & 31 & 68,9 & 36 & 80 & 44 & 97,8 \\
\hline ARV Diminum Seumur Hidup & 32 & 71,1 & 29 & 64,4 & 35 & 77,8 & 44 & 97,8 \\
\hline Efeksamping ARV & 26 & 57,8 & 26 & 57,8 & 25 & 55,6 & 37 & 82,2 \\
\hline Dampak kerja ARV dalam Tubuh & 27 & 60 & 26 & 57,8 & 22 & 48,9 & 30 & 66,7 \\
\hline Mean & 4,71 & 59,17 & 4,67 & 58,33 & 5,31 & 66,68 & 7,04 & 88,06 \\
\hline
\end{tabular}

Sumber: Data Primer Tahun 2016

Tabel 4. Distribusi Frekuensi Kepatuhan Responden Minum ARV di Poli Carlo PKSC dan Poli Rajal IPD RSUP Persahabatan Jakarta, Mei-Juni 2016

\begin{tabular}{ccccccccc}
\hline \multirow{2}{*}{ Kepatuan } & \multicolumn{3}{c}{ Kelompok Kontrol } & \multicolumn{3}{c}{ Kelompok Intervensi } \\
\cline { 2 - 9 } & \multicolumn{2}{c}{ Minggu I } & \multicolumn{2}{c}{ Minggu II } & \multicolumn{2}{c}{ Minggu I } & \multicolumn{2}{c}{ Minggu II } \\
\cline { 2 - 9 } & $\mathbf{n}$ & $\mathbf{0}$ & $\mathbf{n}$ & $\mathbf{0}$ & $\mathbf{n}$ & $\mathbf{\%}$ & $\mathbf{n}$ & $\%$ \\
\hline Kepatuhan Baik & 4 & 8,9 & 3 & 6,7 & 19 & 42,2 & 43 & 95,6 \\
Kepatuhan Sedang & 36 & 80 & 38 & 84,4 & 26 & 57,8 & 2 & 4,4 \\
Kepatuhan Rendah & 5 & 11,1 & 4 & 8,9 & 0 & 0 & 0 & 0 \\
Mean & 2,02 & 33,33 & 2,02 & 33,33 & 1,57 & 33,33 & 1.04 & 33,33 \\
\hline
\end{tabular}

Sumber: Data Primer Tahun 2016 
Tabel 5. Pengaruh Promosi Kesehatan Nola Pender dengan Peningkatan

Pengetahuan pada ODHA di Poli Carlo PKSC dan Poli Rajal IPD RSUP

Persahabatan Jakarta, Mei-Juni 2016

\begin{tabular}{lccccccc}
\hline \multirow{2}{*}{ Promosi Kesehatan } & \multicolumn{4}{c}{ Pengetahuan } & \multirow{2}{*}{ Total } & \multirow{2}{*}{$\boldsymbol{p}$-value } \\
\cline { 2 - 5 } & \multicolumn{2}{c}{ Tidak Meningkat } & \multicolumn{2}{c}{ Meningkat } & & \\
\cline { 2 - 5 } & $\mathbf{n}$ & $\mathbf{\%}$ & $\mathbf{n}$ & $\mathbf{\%}$ & & \\
\hline Kelompok Kontrol & 39 & 86,7 & 6 & 13,3 & 100 & 0,000 \\
Kelompok Intervensi & 4 & 8,9 & 41 & 91,1 & 100 & \\
\hline
\end{tabular}

Sumber: Data Primer Tahun 2016

Tabel 6. Pengaruh antara promosi kesehatan Nola Pender dengan peningkatan pengetahuan pada ODHA di di Poli Carlo PKSC dan Poli Rajal IPD RSUP Persahabatan Jakarta, Mei-Juni 2016

\begin{tabular}{lccccccc}
\hline \multirow{2}{*}{ Pengetahuan } & \multicolumn{4}{c}{ Pengetahuan } & \multirow{2}{*}{ Total } & p-value \\
\cline { 2 - 5 } & \multicolumn{2}{c}{ Tidak Meningkat } & \multicolumn{2}{c}{ Meningkat } & & \\
\cline { 2 - 5 } & $\mathbf{n}$ & $\mathbf{\%}$ & $\mathbf{n}$ & $\mathbf{\%}$ & & \\
\hline Kelompok Kontrol & 30 & 69,8 & 13 & 30,2 & 100 & 0,000 \\
Kelompok Intervensi & 6 & 12,8 & 41 & 87,2 & 100 & \\
\hline
\end{tabular}

Sumber: Data Primer Tahun 2016

bermakna antara peningkatan pengetahuan terhadap peningkatan kepatuhan ( $p$-value 0,000).

\section{Analisis Multivariat}

Penelitian ini menganalisis pengaruh promosi kesehatan Nola Pender dan variabel perancu (usia, jenis kelamin, pendidikan, pekerjaan dan layanan konseling sebelumnya) yang berpengaruh terhadap peningkatan pengetahuan ODHA tentang ARV. Selain itu menganalisis peningkatan pengetahuan dan variabel perancu (dukungan keluarga, dukungan teman sebaya, jarak dan jaminan layanan kesehatan) yang berpengaruh terhadap peningkatan kepatuhan ODHA minum ARV di PK Sint Carolus dan RSUP Persahabatan Jakarta. Analisis multivariat dengan menggunakan uji regresi logistik binary yaitu untuk mengkaji tingkat probabilitas perlakuan promosi kesehatan Nola Pender pada pasien ODHA, dengan $p$-value $<0,25$.

Berdasarkan Tabel 7 diketahui bahwa pada hasil akhir uji regresi logistik binary membuktikan adanya pengaruh antara promosi kesehatan Nola Pender dengan peningkatan pengetahuan dengan $p$-value $=0,000$. Responden yang mendapat promosi kesehatan Nola Pender pada kelompok intervensi mempunyai peningkatan pengetahuan minum ARV sebanyak 71,8 kali dibandingkan yang tidak mendapatkan promosi kesehatan Nola Pender. Tidak terdapat variabel perancu yang mempengaruhi peningkatan pengetahuan.

Promosi kesehatan untuk ODHA diberikan secara terus menerus yang dimulai dengan konseling secara terstruktur dan terprogram dan konseling disesuaikan dengan tahapannya (25). Keefektifan promosi kesehatan Nola Pender dipengaruhi oleh hakekat, motivasi individu dan dukungan lingkungan, derajat kesehatan yang dimiliki seseorang, derajat mental seseorang pada saat dimulainya intervensi promosi kesehatan Nola Pender, didukung dengan hal lainnya seperti kemampuan penyampaian berkenaan dengan permasalahan tertentu dan motivasi peneliti. Indikator yang dapat digunakan dalam mengukur efektifitas promosi kesehatan Nola Pender adalah adanya perubahan perilaku, kesehatan mental yang positif, pemecahan masalah, mencapai keefektifan pribadi dan pengambilan keputusan oleh pasien (26).

Terkait pasien HIVIAIDS perubahan perilaku lebih diarahkan untuk meningkatkan kualitas hidup pasien untuk tidak menularkan penyakitnya ke orang lain, melakukan pengobatan sesuai kondisinya, pasien belajar bertanggung jawab, mencari solusi dari permasalahan yang timbul secara sehat dan efektif, ODHA menjadi lebih patuh minum ARV.

Pengetahuan seseorang dapat dipengaruhi oleh beberapa faktor (7). Faktor yang mempengaruhi pengetahuan seseorang adalah pengalaman, tingkat pendidikan, keyakinan, fasilitas, penghasilan dan sosial. Semakin tinggi pengetahuan seseorang maka akan mempunyai kemampuan yang lebih dalam mendukung proses adaptif, melakukan pencegahan dan mempromosikan kesehatan. Pengetahuan merupakan faktor yang sangat penting untuk 
Tabel 7. Hasil Uji Regresi Logistik Binary antara Intervensi Promosi Kesehatan Nola Pender dan Peningkatan Pengetahuan pada ODHA di Poli Carlo PKSC dan Poli Rajal IPD RSUP Persahabatan Jakarta, Mei-Juni 2016

\begin{tabular}{llrrrrr}
\hline \multicolumn{1}{c}{ Variabel } & \multirow{2}{*}{ B } & \multirow{2}{*}{ Sig. } & \multirow{2}{*}{ Exp(B) } & \multicolumn{2}{c}{ 95\% Cl for Exp (B) } \\
\cline { 6 - 7 } Step 4 & & & & Lower & Upper \\
\cline { 5 - 7 } & Pekerjaan & 1,380 &, 090 & 3,973 &, 808 & 19,547 \\
& Peningkatan Pengetahuan & 4,274 &, 000 & 71,791 & 17,248 & 298,815 \\
& Constant & $-8,561$ &, 000 &, 000 & & \\
\hline
\end{tabular}

Sumber: Data Primer Tahun 2016

Tabel 8. Hasil Uji Regresi Linier Binary antara Peningkatan Pengetahuan dan Kepatuhan pada ODHA di Poli Carlo PKSC dan Poli Rajal IPD RSUP Persahabatan Jakarta, Mei-Juni 2016

\begin{tabular}{llccccc}
\hline & \multirow{2}{*}{ Variabel } & \multirow{2}{*}{ B } & \multirow{2}{*}{ Sig. } & \multirow{2}{*}{ Exp(B) } & \multicolumn{2}{c}{ 95\% Cl for Exp (B) } \\
\cline { 6 - 7 } & & & & Lower & Upper \\
\hline \multirow{3}{*}{ Step 1 1a $^{\text {a }}$} & Dukungan Sebaya &, 051 &, 590 & 3,168 &, 997 & 10,070 \\
& Peningkatan Kepatuhan &, 000 &, 590 & 18,708 & 5,881 & 59,514 \\
& Constant &, 000 & 1,461 &, 003 & & \\
\hline
\end{tabular}

Sumber: Data Primer Tahun 2016

terbentuknya tindakan atau perilaku seseorang dan menguatkan seseorang dalam mengambil keputusan (27). ODHA sebelum mengambil keputusan untuk minum ARV sudah memiliki pengetahuan tentang status kesehatannya dan terapi ARV.

Hasil akhir uji regresi logistik binary tersebut diatas membuktikan bahwa responden yang telah diberikan promosi kesehatan Nola Pender, maka meningkat pengetahuannya mempengaruhi terhadap kepatuhan minum ARV dengan $p$-value $=0,000$. Responden pada kelompok intervensi yang mendapat peningkatan pengetahuan mempunyai peningkatan kepatuhan minum ARV sebanyak 18,7 kali dibandingkan yang tidak mendapatkan peningkatan pengetahuan. Responden yang mendapatkan dukungan teman sebaya mempunyai pengaruh terhadap peningkatan kepatuhan minum ARV sebesar 3,2 kali dibandingkan dengan responden yang tidak mendapat dukungan teman sebaya. Penelitian Aji, tahun 2010 mengungkapkan bahwa dari beberapa variable independen, pengaruh yang paling dominan terhadap kepatuhan ARV adalah pengetahuan terapi ARV dengan exp $B=68,098$. Meningkatkan pengetahuan tentang terapi ARV dengan cara konseling pra terapi ARV, dialog interaktif selama pertemuan rutin dan kelompok dukungan sebaya (28).

Peningkatan pengetahuan ODHA tentang kepatuhannya dapat ditingkatkan melalui promosi kesehatan Nola Pender yang diharapkan dapat meningkatkan sikap kesadaran akan perilaku sehat dengan meningkatkan kepatuhan ODHA minum ARV. Teori HPM mendefinisikan kesehatan sebagai suatu keadaan yang dinamis yang positif bukan hanya tidak adanya penyakit. Model promosi kesehatan ini menggambarkan sifat multi dimensi manusia untuk meningkatkan kemampuannya melakukan perubahan perilaku untuk mendapatkan manfaat bagi dirinya. Pemanfaatan diri yang baik akan memberikan hasil yang positif bagi kesehatannya (12). ODHA akhirnya mampu merubah perilaku yang positif untuk meningkatan kesehatannya menjadi lebih patuh ARV.

Dukungan sebaya mempengaruhi ODHA meningkatkan kepatuhan minum ARV sebesar 3,2 kali. ODHA yang mendapatkan dukungan sebaya berpengaruh pada tingkat kepercayaan diri, pengetahuan HIV dan kegiatan positif yang lebih tinggi dibanding ODHA yang tidak mendapat dukungan sebaya, Kelompok Dukungan Sebaya (KDS) juga membantu ODHA mengurangi stigma dan diskriminasi. Hasil penelitian ini sesuai dengan penelitian yang menyatakan bahwa KDS mempunyai tugas memberikan motivasi dan mendampingi ODHA dengan menjelaskan secara mendalam mengenai penyakit HIVIAIDS dan kepatuhan ARV, peran KDS adalah sangat baik $57 \%$ dan kepatuhan minum obat $63 \%$ dengan kepatuhan baik (kepatuhan $>95 \%$ ). Ada hubungan yang signifikan antara KDS dengan kepatuhan minum obat pada ODHA nilai $p$-value $=0,000$.(29) Penelitian Markos mengungkapkan dari 291 responden yang menjalani 
terapi ARV, 22\% tidak memiliki dukungan sosial dan $88,3 \%$ memiliki dukungan, sehingga responden yang memiliki dukungan memiliki pengetahuan yang baik tentang kepatuhan, manfaat ARV dan kelayakan menjalani ARV adalah 68\%, 28,2\% dan $57,7 \%$ (30).

Berdasarkan pengalaman peneliti dan sesuai seperti yang diungkapkan oleh Pender, 2011 bahwa pengaruh situasional dari KDS pada lingkungan eksternal dapat meningkatkan komitmen untuk berpartisipasi dalam berperilaku sehat meningkatkan kepatuhan ARV. Karena sebagian ODHA yang melakukan kunjungan ditemani KDS terlihat merasa lebih bersemangat, mempunyai keyakinan diri untuk berkomitmen berbuat dan berperilaku sehat. Selain aktif dalam peran mencegah penularan HIVIAIDS lebih lanjut dan komitmen untuk lebih patuh ARV sehingga bermanfaat untuk kesehatannya (11).

\section{SIMPULAN DAN SARAN}

Karakteristik dari keseluruhan responden ODHA, yang terbanyak adalah usia dewasa akhir, dengan pendidikan lanjut dan pernah mendapat layanan konseling, mendapat dukungan keluarga, mendapat dukungan teman sebaya, jarak layanan kesehatan mudah ditempuh dan mendapat jaminan layanan kesehatan.

Promosi kesehatan Nola Pender meningkatkan pengetahuan tentang ARV dari rata-rata nilai 5,31 menjadi 7,04 dan meningkatkan kepatuhan minum ARV dari kepatuhan sedang menjadi kepatuhan baik sebanyak 95,6\%. Pengaruh promosi kesehatan Nola Pender dengan menggunakan booklet meningkatkan pengetahuan responden $(p=0,000)$ sebanyak $91,1 \%$. Peningkatan pengetahuan tentang ARV berpengaruh terhadap kepatuhan minum ARV $(p=0,000)$, dikontrol oleh variabel dukungan teman sebaya, sebanyak $87,2 \%$. Rekomendasi penelitian ini perlu dilanjutkan promosi kesehatan Nola Pender pada ODHA dengan ARV yang terprogram dan terstruktur secara berkelanjutan.

\section{RUJUKAN}

1. Black J, Hawk. Medical Surgical Nursing. Singapura: Elsevier (Singapura) Pte Ltd; 2014.

2. Brunner S. Textbook of Medical Surgical Nursing. Philadelphia: Wolters Kluwer, Lippincott Williams \& Wilkins; 2014.

3. Hansana V, Sanchaisuriya P, Durham J, Sychareun V, Chaleunvong K, Boonyaleepun S, et al. Adherence to antiretroviral therapy (ART) among people living with HIV (PLHIV): a crosssectional survey to measure in Lao PDR. BMC Public Health [Internet]. 2013 Jun 28;13:617. Available from: http://www.ncbi.nlm.nih.gov/ pubmed/23809431.

4. Wright S, Boyd MA, Yunihastuti E, Law M, Sirisanthana T, Hoy J, et al. Rates and factors associated with major modifications to first-line combination antiretroviral therapy: results from the Asia-Pacific region. PLoS One [Internet]. 2013;8(6):e64902. Available from: http://www. ncbi.nlm.nih.gov/pubmed/23840312.

5. Anderson LK. A Model of Learning Objectives, A taxonomy for learning, teaching and assessing; A revision of Bloom,s Taxonomy of Educational Objectives. New York, Longman: IOWA State University; 2016.

6. Ubra RR. Faktor-faktor yang Berhubungan dengan Kepatuhan Pengobatan Minum ARV pada Pasien HIV di Kabupaten Mimika-Provinsi Papua Tahun 2012. Universitas Indonesia; 2012.

7. Notoatmodjo. Promosi Kesehatan, Teori dan Aplikasi. Jakarta: Rineka Cipta; 2012.

8. Olowookere SA, Fatiregun AA, Adewole IF. Knowledge and attitudes regarding HIVIAIDS and antiretroviral therapy among patients at a Nigerian treatment clinic. J Infect Dev Ctries [Internet]. 2012 Nov 26;6(11):809-16. Available from: http:// www.ncbi.nlm.nih.gov/pubmed/23277507.

9. Latif F, Maria IL, Syafar M. Efek Samping Obat terhadap Kepatuhan Pengobatan Antiretroviral Orang dengan HIVIAIDS. Kesmas Natl Public Heal J [Internet]. 2014 Dec 14;9(2):101. Available from: http://journal.fkm.ui.ac.id/kesmas/article/ view/495.

10. Kammerer J, Garry G, Hartigan M, Carter B, Erlich L. Adherence in patients on dialysis: strategies for success. Nephrol Nurs J [Internet]. 2007;34(5):479-86. Available from: http://www. ncbi.nlm.nih.gov/pubmed/18041450.

11. Pender NJ. Health promotion in nursing practice. Boston: Pearson; 2011.

12. Alligood MR. Nursing Theorist and Their Work. Mosby: Elsevier; 2014.

13. Polit DF. Nursing Research: Generating And Assesing Evidence For Nursing Practice. Philippines: Lippincott Williams and Wilkins; 2012.

14. Supardi, Rustika. Metodologi Riset Keperawatan. Jakarta: Trans Info Media; 2013. 
15. Lemeshow, Lwanga. Sample size determination in health studies, A Practical Manual [Internet]. Geneva; 1991 [cited 2016 Feb 6]. Available from: http://apps.who.int/iris/bitstream/10665/40062/1/ 9241544058_\%28p1-p22\%29.pdf.

16. Susilo HS. Biostatika Lanjut dan Aplikasi Riset. Jakarta: TIM Trans Info Media; 2014.

17. Martoni $\mathrm{W}$, Arifin $\mathrm{H}$, Raveinal R. Faktor-Faktor Yang Mempengaruhi Kepatuhan Pasien HIVI AIDS di Poliklinik Khusus Rawat Jalan Bagian Penyakit Dalam RSUP dr. M. Djamil Padang Periode Desember 2011-Maret 2012. J Farm Andalas [Internet]. 2013;1(1):48-52. Available from: http://jfa.ffarmasi.unand.ac.id/index.php/jfa/ article/view/9/8.

18. Safira N, Lubis R, Rasmaliah. Faktor-Faktor yang Berhubungan dengan Kepatuhan Penderita HIV/ AIDS Mengkonsumsi Obat Antiretroviral (ARV) di Klinik Voluntary Counseling and Testing (VCT) RSUP H.Adam Malik Medan tahun 2014. Gizi, Kesehat reproduksi dan Epidemiol [Internet]. 2015;1(4):1-10. Available from: http://jurnal.usu. ac.id/index.php/gkre/article/view/11454.

19. Chanvilay T, Yoshida Y, Reyer JA, Hamajima N. Factors associated with access to antiretroviral therapy among people living with hiv in vientiane capital, lao pdr. Nagoya J Med Sci [Internet]. 2015 Feb;77(1-2):29-39. Available from: http://www. ncbi.nlm.nih.gov/pubmed/25797968.

20. Chaiyachati $\mathrm{KH}$, Ogbuoji $O$, Price $M$, Suthar $A B$, Negussie EK, Bärnighausen T. Interventions to improve adherence to antiretroviral therapy: a rapid systematic review. AIDS [Internet]. 2014 Mar;28 Suppl 2:S187-204. Available from: http:// www.ncbi.nlm.nih.gov/pubmed/24849479.

21. Yuniar Y, Handayani RS, Aryastami NK. FaktorFaktor Pendukung Kepatuhan Orang dengan HIV/ AIDS (ODHA) dalam Minum Obat Antiretroviral di Kota Bandung dan Cimahi. Bul Penelit Kesehat [Internet]. 2013;41(2):72-83. Available from: http://ejournal.litbang.depkes.go.id/index.php/ BPK/article/view/3154/3125.
22. Friedman BJ. Buku ajar keperawatan keluarga, riset, teori dan praktik. 5th ed. Jakarta: EGC; 2010.

23. Parrisbalogun $S$. Adherence. In: Loue $S$, editor. Mental Health Practitioner's Guide to HIVIAIDS. Springer-Verlag New York; 2013. p. 75-6.

24. Campbell C, Scott K, Madanhire C, Nyamukapa C, Gregson S. A "good hospital": nurse and patient perceptions of good clinical care for HIV-positive people on antiretroviral treatment in rural Zimbabwe-a mixed-methods qualitative study. Int J Nurs Stud [Internet]. $2011 \mathrm{Feb} ; 48(2): 175-83$. Available from: http://www.ncbi.nlm.nih.gov/pubmed/20801450.

25. Tucker JD, Bien CH, Easterbrook PJ, Doherty MC, Penazzato M, Vitoria M, et al. Optimal strategies for monitoring response to antiretroviral therapy in HIVinfected adults, adolescents, children and pregnant women: a systematic review. AIDS [Internet]. 2014 Mar;28 Suppl 2:S151-60. Available from: http:// www.ncbi.nlm.nih.gov/pubmed/24849475.

26. Peterson SJ, Bredow TS. Middle Range Theories: Application to Nursing Research. 3rd ed. Philadelphia: Wolters Kluwer, Lippincott Williams \& Wilkins; 2013. 224-233 p.

27. Kemenkes RI. Tatalaksana klinis infeksi HIVIAIDS dan terapi Antiretroviral pada orang dewasa. In: Pedoman Nasional, Kementerian kesehatan RI Direktorat Jenderal Pengendalian Penyakit dan Penyehatan Lingkungan. Jakarta: Bakti Husada; 2011.

28. Aji HS. Faktor-Faktor yang Mempengaruhi Kepatuhan Pasien HIV dan AIDS terhadap terapi Antiretroviral di RSUP dr. Kariadi Semarang. J Promosi Kesehat Indones. 2010;5(1).

29. Yuswanto TJA, Wahyuni TD, Pitoyo J. Peran Kelompok Dukungan Sebaya(KDS) dan Kepatuhan Minum Obat pada ODHA. J Pendidik Khusus. 2015;4(1):64-9.

30. Markos E, Worku A, Davey G. Adherence to ART in PLWHA and Yirgalem Hospital, South Ethiopia. Ethiop J Heal Dev [Internet]. 2009 Feb 4;22(2). Available from: http://www.ajol.info/index.php/ejhd/ article/view/10068. 